\title{
Advances in experimental methods for root system architecture and root development
}

\author{
Jun-bang Wang $\cdot$ Xiu-juan Zhang $\cdot$ Chu Wu
}

Received: 17 September 2013/Accepted: 15 April 2014/Published online: 15 January 2015

(C) Northeast Forestry University and Springer-Verlag Berlin Heidelberg 2015

\begin{abstract}
Plant roots play important roles in acquisition of water and nutrients, storage, anchoring, transport, and symbiosis with soil microorganisms, thus quantitative researches on root developmental processes are essential to understand root functions and root turnover in ecosystems, and at the same time such researches are the most difficult because roots are hidden underground. Therefore, how to investigate efficiently root functions and root dynamics is the core aspect in underground ecology. In this article, we reviewed some experimental methods used in root researches on root development and root system architecture, and summarized the advantages and shortages of these methods. Based on the analyses, we proposed three new ways to more understand root processes: (1) new experimental materials for root development; (2) a new observatory system comprised of multiple components, including many observatory windows installed in field, analysis software,
\end{abstract}

Project funding: This work is supported by the project of public benefits in China (No. 201503221) and the open fund in the Institute of Root Biology, Yangtze University.

The online version is available at http://www.springerlink.com

Corresponding editor: Chai Ruihai

J. Wang

Key Laboratory of Ecosystem Network Observation and Modeling, Institute of Geographic Sciences and Natural Resources Research, Chinese Academy of Sciences,

Beijing 100101, China

e-mail: jbwang@igsnrr.ac.cn

X. Zhang · C. Wu (凶)

College of Horticulture and Gardening, Yangtze University,

Jingzhou 434025, Hubei, China

e-mail: wuchuchu2001@126.com and automatic data transport devices; (3) new techniques used to analyze quantitatively functional roots.

Keywords Root system analysis - Fractal geometry · Novel materials

\section{Introduction}

There are great differences in development between aboveand below-ground parts of plants. The development of above-ground plant parts is less affected by environmental factors, thus branching patterns of above-ground parts are similar among individuals of the same species. In contrast, the development of root systems is greatly affected by the soil environmental factors, such as soil nutrients (especially the availability of nitrogen and phosphate) (Zhang and Forde 1998; Williamson et al. 2001; Linkohr et al. 2002; Wu et al. 2005; Hill et al. 2006; Jain et al. 2007; Vidal et al. 2010; Peret et al. 2011; Gan et al. 2012; Gruber et al. 2013; White et al. 2013), soil water (Berntson and Woodward 1992; Manschadi et al. 2006, 2008; Henry et al. 2011; Bengough et al. 2011), soil temperature (Mackay and Barber 1984; Kaspar and Bland 1992; Clausnitzer and Hopmans 1994), soil pH (Walter et al. 2000), soil compaction (Bushamuka and Zobel 1998; Busscher et al. 2000; Tracy et al. 2010a), and slope gradients (Di Iorio et al. 2005; Pierret et al. 2007; Sun et al. 2008), thus the morphology and physiology of roots show great plasticity. Because of the relationships between above- and belowground parts of plants, it is necessary to maximize root/ rhizosphere efficiency to improve plant productivity and nutrient efficiency (Shen et al. 2013). Root traits can be used to create phosphate efficient crop varieties in response to limited global phosphate resources (Gahoonia and 
Nielsen 2004). Therefore, root development, root system architecture, and root dynamics have been the focuses in botany and ecology. An obstacle to the study of root system architecture is to measure and quantify the three-dimensional configuration of root systems in soil. At the same, root dynamics is not monitored efficiently because of hidden roots in dark medium. Researchers have attempted to overcome the two obstacles in order to understand root functions and root responses to soil environmental factors. In this paper, we review some advantages and shortages in experimental methods for study of root development, root system architecture, and root dynamics, and propose some new ways to enhance root research.

\section{The theoretic bases for analysis of root system}

Root system architecture, as defined by Lynch (1995), refers to the spatial configuration of the root system, i.e. the explicit geometric deployment of the root axes. The root system architecture of plant seedlings is relatively simple but adult plants, especially adult trees, such as Sequoia sempervirens, have complex root system architecture (Nadezhdina and Čermák 2003; Di Iorio et al. 2005) that is difficult to study.

Although plant root systems show plasticity and complexity, within a given species root systems are similar because of shared genetic characteristics. The similarity provides the basis for their analysis.

Mandelbrot (1975) coined the term "fractal". A fractal is generally a rough or fragmented geometric shape that can be split into parts, each of which is (at least approximately) a reduced-size copy of the whole shape, i.e. self-similarity. A fractal often has traits including: (1) self-similarity; (2) fine or detailed structure at arbitrarily small scales; (3) simple and recursive definition; (4) irregularity which is difficult to describe by Euclidean geometry; (5) Hausdorff dimension which is greater than its topological dimension. Based these traits of fractals, smaller parts of roots are fractal representations of larger parts of roots, thus fractal analysis is an appropriate tool for study of root systems. Therefore, fractal analysis was used to describe root systems of many plant species (Table 1). Fractal analysis has also been used to compare the responses of root system architecture to nutrient deficiency (Eghball et al. 1993; Nielsen et al. 1999), drought stress (Wang et al. 2009), and efficiency of soil exploration by roots (Walk et al. 2004).

These applications of fractal analysis are deficient because they were only involved in two-dimension structures of root systems, and spatial configurations of root systems are not taken into consideration. In natural ecosystems, most soil nutrients are in the soil layer of $10-20 \mathrm{~cm}$ deep, thus root spatial configurations are related to nutrition uptake.
Therefore, some parameters involved in description for root spatial configuration, such as the angles between primary root and the first lateral roots and the angles between root links in a root system, should be analyzed in fractal analysis. Data obtained from a complex root system are great, thus new software will be developed for analyzing them.

Root topology is another term used for delineation of root systems. As defined by Lynch (1995), the term refers to how individual root axes are connected to each other through branching. Unlike branching of above-ground parts, root branching shows great spatiotemporal changes, for example, first-order fine roots can be connected with second-order and the third-order roots (Pregitzer et al. 2002), and even with fourth-order roots (Wang et al. 2006), leading to the complexity of root branching. Regardless of its complexity, root branching links can be classified into three types, i.e. exterior-exterior (EE), exterior-interior (EI), and interior-interior (II) (Fig. 1, Fitter and Stickland 1991).

Three topological parameters can be calculated to describe the relationships between links:

Magnitude $(\alpha)$ : number of exterior links. The total number of root tips categorized as EI and EE (Fig. 1a) or total numbers of root tips categorized a EE (Fig. 1b).

Altitude $(\mu)$ : number of links in the longest unique path from the base link to an exterior link. In Fig. 1a, from an exterior link labeled EE to the base link, the number of root links is 10 , i.e. $\mu=10$. In Fig. $1 b$, from any exterior link labeled $\mathrm{EE}$ to the base link, the number of root links is 4 , i.e. $\mu=4$.

Total exterior pathlength $\left(p_{\mathrm{e}}\right)$ : sum of numbers of links in all possible unique paths from the base link to all exterior links. In Fig. 1a, $p_{\mathrm{e}}=64$; in Fig. $1 \mathrm{~b}, p_{\mathrm{e}}=32$.

Two topological indices can be used

Altitude-slope: the slope of the regression of $\log _{10} \alpha$ on $\log _{10} \mu$ for a given root system. In the plot with $\log _{10} \mu$ as the $\mathrm{x}$ axis and $\log _{10} \alpha$ as the $\mathrm{y}$ axis, the slope of the regression is the altitude-slope for a set of root system.

Pathlength-slope: the slope of the regression of $\log _{10} p_{\mathrm{e}}$ on $\log _{10} \mu$ for a given root system. In the plot with $\log _{10} \mu$ as the $\mathrm{x}$ axis and $\log _{10} p_{\mathrm{e}}$ as the $\mathrm{y}$ axis, the slope of the regression is the pathlength-slope for a given root system.

In addition, some parameters are used to describe the morphology of root systems, such as root hair density, root diameter, the occurrence pattern of lateral roots, the distance from the tip to the lattermost lateral root. Anatomical traits such as the sizes of epidermal cells in the elongation zone, the cell density of the meristem zone, and the size of meristem zone are not usually involved in the description of root systems.

Similar to fractal analysis, root topology does not take root spatial configuration into consideration. 
Table 1 The plant species which were analyzed using fractal analysis

\begin{tabular}{ll}
\hline Plant species & References \\
\hline Phaseolus vulgaris & Nielsen et al. (1997, 1999); Walk et al. (2004) \\
Betula populifolia & Berntson (1994) \\
Betula alleghaniensis & Berntson (1994) \\
Zea mays & Costa et al. (2003); Tatsumi et al. (1989); Eghball et al. (1993) \\
Arachis hypogaea & Tatsumi et al. (1989) \\
Panicum miliaceum & Tatsumi et al. (1989) \\
Pisum sativum & Tatsumi et al. (1989) \\
Secale cereale & Tatsumi et al. (1989) \\
Sorghum bicolor & Tatsumi et al. (1989) \\
Triticum aestivum & Tatsumi et al. (1989) \\
Trifolium pratense & Fitter and Stickland (1992) \\
Trifollium repens & Fitter and Stickland (1992) \\
Plantago lanceolata & Fitter and Stickland (1992) \\
Festuca voina & Fitter and Stickland (1992) \\
Festuca nigrescens & Fitter and Stickland (1992) \\
Oryza sativa & Wang et al. (2009) \\
Strychnos cocculoides & Oppelt et al. (2000) \\
Strychnos spinosa & Oppelt et al. (2000) \\
Vangueria infausta & Oppelt et al. (2000) \\
Grewia flava & Oppelt et al. (2000) \\
Reaumuria soongorica & Shan et al. (2013) \\
Nitraria tangutorum & Shan et al. (2013) \\
\hline
\end{tabular}
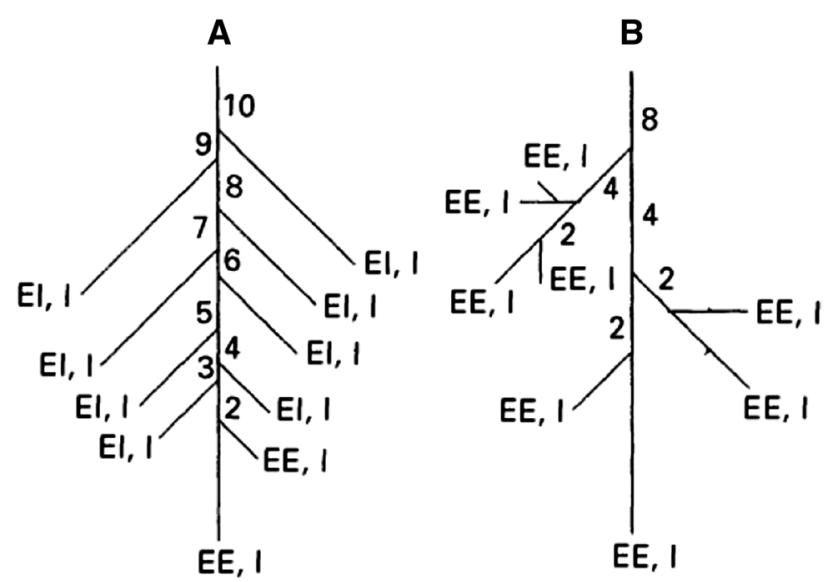

Fig. 1 Diagram showing the distinction between extreme branching patterns (a: herringbone; b: dichotomous). Exterior-exterior (EE); exterior-interior (EI); interior-interior (II) [e.g. a link between the two dashed lines in (b) cited from (Fitter and Stickland 1991]

\section{Experimental methods for measurement of root systems}

The complexity of root system architecture raises obstacles to data acquisition that are addressed by advances in technology. Digital images help to quickly acquire data about root system architecture. Meanwhile, related software is helpful for processing these data.
Root system analysis technologies based on scanners were developed, including WinRhizo and RootSnap. Specific root analysis software was also developed, including Multi-ADAPT (Ishikawa and Evans 1997), AMAPmod (Danjon et al. 1999a, b, 2008), Delta-T Scan and WinRHIZO (Boumma et al. 2000), REGR (Walter et al. 2002), RootFlow (van der Weele et al. 2003, KineRoot (Basu et al. 2007), SmartRoot (International Atomic Energy Agency 2006; Draye 2008), RootLM (Qi et al. 2007), Phytomorph (Miller et al. 2007; Spalding, 2009), RootNav (Pound et al. 2013), RootTrace (French et al. 2009), and Growth Tracer (Iwamoto et al. 2013). RootFlow and REGR made use of optic flow-based techniques (Barron et al. 1994; Barron and Liptay 1994). All of these applications have their strengths and weaknesses. The combination of scanner and software was used to measure some root parameters using three-dimension techniques that provided more configuration information about root system architecture (Danjon and Reubens 2008). For entire root systems, some morphological traits can be analyzed, including total root length, root average diameter, total root surface, project surface, root tips, root volume. Some parameters related to root links can be measured, such as total number of links in a root system, their average length and diameter, volume, and branching angles. Topological parameters can also be measured, such as altitude, magnitude, and exterior path length. 
Some root analysis systems have their shortcomings, one of which is the fact that roots must be excavated and washed from soil cores before they can be scanned (Gregory 2006; Smit et al. 2000). Excavation and washing must break some parts of the root system, leading to the underestimation of fine roots through breakage and loss of information on the spatial distribution and root system architecture. More seriously, data obtained later are lack of the information about root spatial configuration.

More advanced devices were developed. More than ten years ago, X-ray computed tomography (CT) was first used to analyze root systems (Heeraman et al. 1997; Pierret et al. 1999). Because the scanning process of X-ray CT is nondestructive, the technique can track root growth and changes in root system architecture. Based on these advantages, the technique has been developed and widely used (Gregory et al. 2003; Lontoc-Roy et al. 2005; Perret et al. 2007; Tracy et al. 2010a, b; 2012a, b; Mooney et al. 2012; Mairhofer et al. 2012, 2013).

X-ray CT can visualize the internal structure of opaque objects. X-ray CT scanners acquire a series of projections from different facets of a vessel that contains plants, measuring the attenuation of ionizing radiation passing through the vessel. These projections are combined to reconstruct a three-dimensional data set. Data values recorded at each voxel reflect the density of the imaged material and are usually mapped to greyscale intensity values for visualization purposes (Mooney 2002). But variations in the $\mathrm{x}$-ray attenuation values of root material and the overlap in attenuation values between roots and soil caused by water and organic materials (especially nondecomposed litter) represent major challenges to data recovery. Software (such as RooTrack) has been developed to separate root systems from their soil environment in images obtained by X-ray CT and recover root system architecture traits (Mairhofer et al. 2012, 2013).

In addition, as a complementary tool to other predictive techniques, gel growth systems with superior optical clarity have been introduced to facilitate noninvasive twodimensional (2D; Iyer-Pascuzzi et al. 2010) and threedimensional (3D; Fang et al. 2009; Clark et al. 2010) imaging. These methods are only used for root systems of seedlings, thus its applications are limited.

At present, there are not available techniques used in field for in situ dynamic observation. Ground penetrating radar (GPR) should be useful to investigate root systems of forest trees on forest ecosystem level (Nadezhdina and Čermák 2003; Butnor et al. 2003; Barton and Montagu 2004; al Hagrey 2007). GPRs have not only the lowest wave length and resolution to detect small targets but also the highest wave attenuation that limits resolution and penetration in wet conducting media, thus they have been used to estimate single root segments or biomass with a relatively low precision (Butnor et al. 2003; Barton and Montagu 2004; al Hagrey 2007). But, at present, the accuracy and resolution of GPRs are not enough for fine roots (root diameter $<1 \mathrm{~mm}$ ), and more advanced GPRs are needed. Software applications have also been developed to analyze information collected by GRP, providing detailed investigation on root systems at the ecosystem level.

Based on the analyses mentioned above, two new techniques will be developed: one is the combination of continuous three-dimensional imaging and fractal analysis/ topology used in laboratories; another is in situ continuous multiple-site observatory root systems with automatic data transport used in ecosystem level.

\section{Novel plant materials used in root development}

Root development includes three main aspects, i.e. elongation of roots, branching (including proteoid roots), and differentiation of root epidermal cells (i.e. root hair formation, including dauciform roots; Playsted et al. 2006; Shane et al. 2006). Lateral root formation is the base of development of the whole root system in which root elongation enlarges the volume of soil explored by roots, and root hairs greatly increase the absorptive surface area for water and nutrients in soil. Of the three aspects, lateral root formation seems more important, thus investigation on lateral root formation has been the focus of the root development research. While various types of advanced microscopes are used in studies of root development, new plant materials are also used. Many mutants related to specific genes that affect root development and many transgenic Arabidopsis lines with GFP or GUS in root tissues showed novel traits, i.e. specific occurrence in a tissue in roots. Thus these transgenic plants are often used in studies of root development. Lateral root formation starts with a series of anticlinal and periclinal divisions of pericycle cells, a layer of root tissue surrounding the vasculature (Malamy and Benfey 1997; Kurup et al. 2005). Thus, detection of the activity of pericycle cells near the xylem poles is important for lateral root formation. Quiescent centers (QC) in root tips maintain the activities and sizes of the meristems in roots, so detection of QC is also important.

In the MRC Laboratory of Molecular Biology, led by Jim Haseloff (http://data.plantsci.cam.ac.uk/Haseloff/), GAL4GFP lines were produced by Agrobacterium-mediated transformation of the $\mathrm{C} 24$ Arabidopsis line using the binary vector pBIN m-gfp5-ER. The $m$-gfp5-ER gene is GAL4 responsive and is linked to a GAL4 gene, a foreign transcription activator derived from the yeast GAL4 gene in the GAL4-GFP lines. Because of the traits of GFP, the patterns of GAL4 expression in the GAL4-GFP lines can be immediately and directly detected. Some lines in the GAL4- 
GFP set show specific patterns of GAL4 expression in roots, thus they are widely used in studies on root development.

Of all the GAL4-GFP lines, J0121 seems to be the most useful for studies on root development. In J0121, GAL4::GFP expression is specific to 2-3 root pericycle cell files adjacent to the xylem poles (Fig. 2; Laplaze et al. $2005)$, thus the line can be used for detection of the first cell division of cells at the initial stage of lateral root formation. In J0192, GAL4::GFP is expressed in young lateral root primordia (Fig. 2; Laplaze et al. 2005), thus it is very useful for detecting the development of young lateral root primordial. After these two lines were produced, they have often been used in studies of root systems (Table 2).

Most recently, a GAL4-based targeted activation tagging system in Arabidopsis has been established (Waki et al. 2013). Host plants that expressed a synthetic transcription activator GAL4:VP16 (GV) in an organ- or tissue-specific manner were transformed with a T-DNA harboring tandem copies of UAS, a GAL4-binding sequence. Thus the activation tagging system is a powerful tool for discovering novel genes that affect root development.
QC maintains the activity of root meristem and specific lines were produced to observe QC status (Table 2). GFP only occurs in QC25, thus QC25 is used in root development, especially used in monitoring the activity of QC and root meristem of plants treated with phytohormones and environmental stresses.

In other GAL4-GFP lines, GFP specifically occurs in columella (Q1630), root epidermis (J2301, J0631, and J2921), lateral root cap (J0951), and stele (J2501) (Table 2).

Lateral roots originate from the pericycle cells opposite to xylem poles. These pericycle cells are distant from the root meristem zone and stop division. Therefore, the first step of lateral root formation is the recovery of the cell cycle of some pericycle cells. CYCB 1;1 is a mitotic cyclin in Arabidopsis, and is expressed only around the G2/M transition in the cell cycle (Doerner et al. 1996; Shaul et al. 1996), therefore, $C y c B 1 ; 1::$ uidA reporter construct (Fig. 3) is often used as the marker to detect the process of the cell cycle during lateral root formation (Table 2; Casimiro et al. 2001; Aida et al. 2004; Hutchison et al. 2006; Ioio et al. 2007).
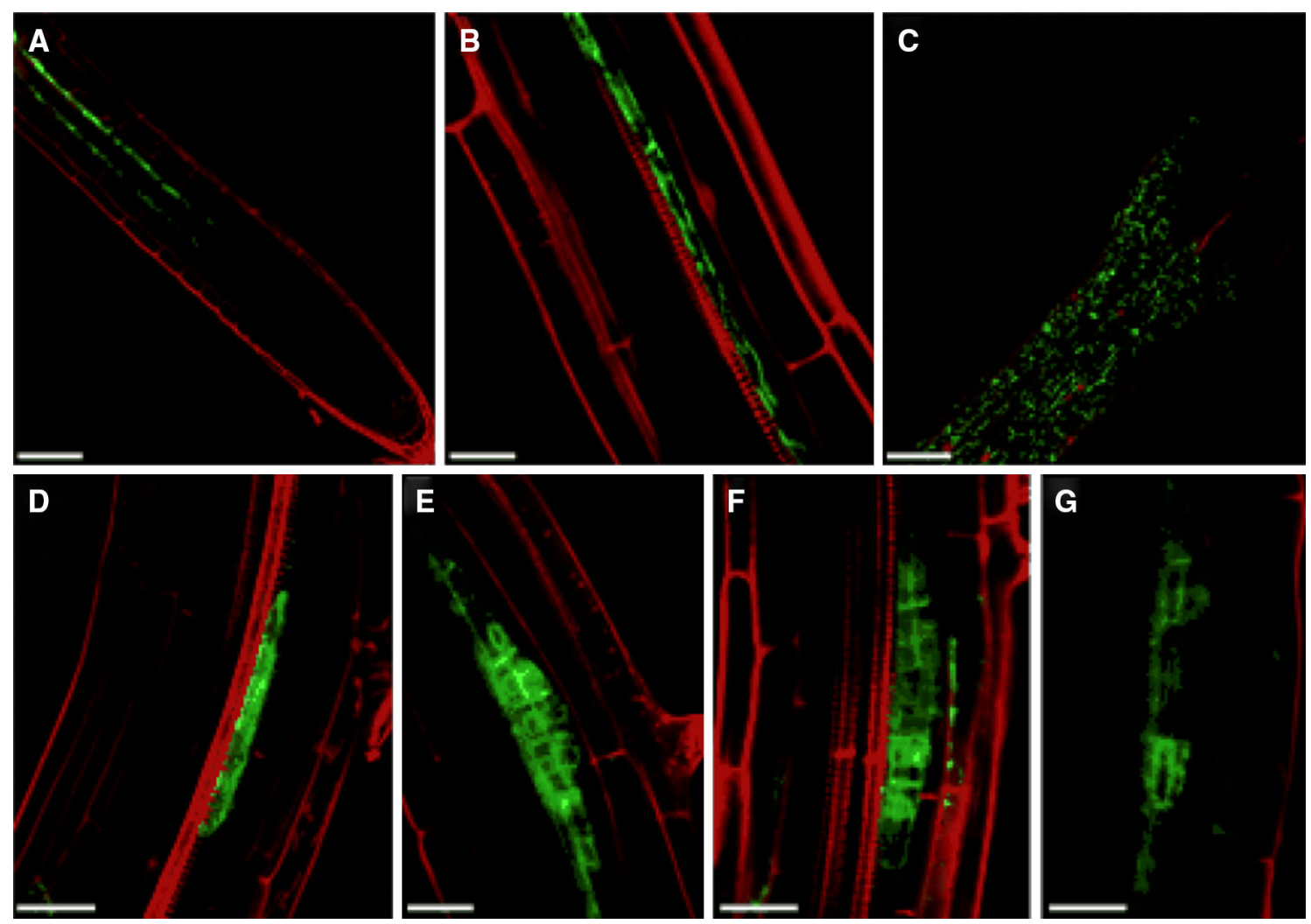

Fig. 2 GFP expression in the enhancer trap lines J0121 (a-c) and J0192 (d-g). (a, b, d, e, f, g) Longitudinal confocal sections of roots and (c) projected confocal view of the top part of a hypocotyl of living plants showing GFP fluorescence (green) and counterstained with propidium iodide (red). a GFP expression starts in the pericycle cells of the elongation zone. No GFP fluorescence is visible in the root meristem. b Expression in pericycle cells adjacent to a xylem strand. c Expression in the hypocotyl epidermis. d Expression in a stage I primordium. e Expression in a stage II primordium. $\mathbf{f}$ Expression in a stage III primordium. g Expression in a stage V primordium. Cited from Laplaze et al. 2005 
Table 2 Experimental materials often used in studies on root development

\begin{tabular}{|c|c|c|}
\hline Material names & Expression patterns & Application \\
\hline J0121 & Xylem pole pericycle & $\begin{array}{l}\text { Dubrovsky et al. (2006), Casimiro et al. (2001), Ohashi-Ito and Bergmann } \\
\text { (2007), Laplaze et al. (2007), Sugimoto et al. (2010) }\end{array}$ \\
\hline J0192 & Young lateral root primodria & Sabatini et al. (2003), Laplaze et al. (2007) \\
\hline J0571 & Cortex & $\begin{array}{l}\text { Sabatini et al. (1999), Casimiro et al.(2001), Sabatini et al. (2003), } \\
\text { Ioio et al. (2007) }\end{array}$ \\
\hline $\mathbf{J} 2301$ & Root epidermis & Sabatini et al. (1999) \\
\hline $\mathbf{J} 2341$ & QC and columella initials & Sabatini et al. (2003), Willemsen et al. (2003), Ding and Friml (2010) \\
\hline $\mathrm{J} 1892$ & Columella & Ioio et al. (2007) \\
\hline J0631 & Epidermis & Ioio et al. (2007) \\
\hline $\mathrm{J} 2921$ & Epidermis & Ioio et al. (2007) \\
\hline $\mathrm{J} 3411$ & Root cap & Birnbaum et al. (2003), Petersson et al. (2009) \\
\hline J0951 & Lateral root cap & Swarup et al. (2005), Petersson et al. (2009) \\
\hline $\mathrm{J} 2812$ & Epidermis and cortex & Petersson et al. (2009) \\
\hline $\mathrm{J} 2501$ & Stele & Petersson et al. (2009) \\
\hline Q1630 & Columella & $\begin{array}{l}\text { Sabatini et al. (1999, 2003); Willemsen et al. (2003), Ohashi-Ito and } \\
\text { Bergmann (2007), Ioio et al. (2007), Ding and Friml, (2010) }\end{array}$ \\
\hline QC25 & $\mathrm{QC}$ & Sabatini et al. (2003), Ohashi-Ito and Bergmann (2007) \\
\hline QC46 & Endodermis & Sabatini et al. (1999, 2003); Willemsen et al. (2003) \\
\hline QC148 & $\mathrm{QC}$ & Sabatini et al. (2003) \\
\hline Q0990 & QC and stele initials & Petersson et al. (2009) \\
\hline M0028 & Root cap, columella, initials, QC & Swarup et al. (2005), Petersson et al. (2009) \\
\hline DR5::GFP/GUS & QC, columella & $\begin{array}{l}\text { Ottenschläger et al. (2003), Willemsen et al. (2003), Laplaze et al. (2007) } \\
\text { Ohashi-Ito et al. (2007), Petersson et al. (2009) }\end{array}$ \\
\hline Pscr::GFP/GUS & Endodermis & $\begin{array}{l}\text { Birnbaum et al. (2003), Sabatini et al. (2003), Petersson et al. (2009), } \\
\text { Sugimoto et al. (2010) }\end{array}$ \\
\hline CYCB $1 ; 1:: G F P / G U S$ & Xylem pole pericycle & $\begin{array}{l}\text { Casimiro et al. (2001), Aida et al. (2004), Hutchison et al. (2006), } \\
\text { Ioio et al. (2007) }\end{array}$ \\
\hline
\end{tabular}

Root development is affected by environmental factors, thus lateral root initiation is a probabilistic event, but its frequency is set by fluctuating levels of auxin response (Laskowski 2013). In Arabidopsis, the process of lateral root formation consists of two major stages: cell cycle reactivation in the xylem pericycle and establishment of a new meristem (Himanen et al. 2002). Pericycle reactivation depends on local concentration of auxin in the roots, whereas the outgrowth of lateral roots is regulated by shoot-derived auxin (Bhalerao et al. 2002). Therefore, detection of local concentration of auxin in roots is very important for lateral root formation and root system development.

There are some auxin-responsive elements (AuxRE) in the promoters of auxin-responsive genes, such as IAA5 and IAA19 genes (Nakamura et al. 2003), and AuxRE contains the TGTCTC sequence. ARF proteins can bind to AuxRE after Aux/IAA proteins are degraded and ARF proteins are released from Aux/IAA proteins, promoting auxin responses. A highly active synthetic AuxRE, referred to as DR5, was created by performing site-directed mutations in a natural composite AuxRE found in the soybean GH3

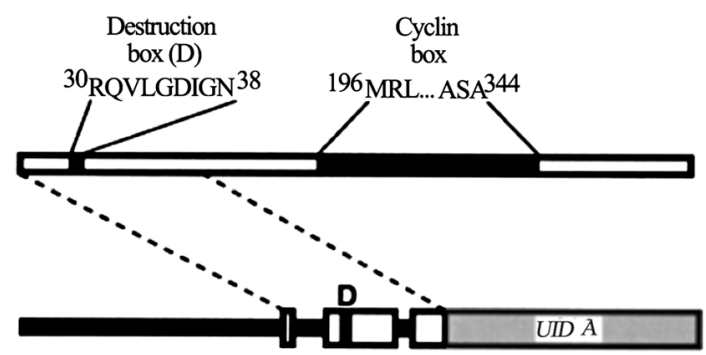

Fig. 3 Schematic of the $C y c B 1 ; 1:$ :uidA reporter construct (pCDG). The upper panel highlights functional motifs of cyclin $C y c B 1 ; 1$. The lower panel shows the $1.8 \mathrm{~kb}$ genomic fragment, including approximately $1.2 \mathrm{~kb}$ of promoter sequence and the first three exons of $C y c B 1 ; 1$ coding sequence up to amino acid 116 , translationally fused to the $E$. coli uidA gene. Thick lines represent promoter sequences or introns, boxes represent exons. Cited from Colón-Carmona et al. 1999

promoter (Ulmasov et al. 1997). Because DR5 showed greater auxin responsiveness than a natural composite AuxRE (as shown in Fig. 4), it became a useful reporter gene (acting as DR5::GFP or DR5::GUS) for studying auxin responses in wild-type plants and various mutants (Sabatini et al. 1999; Friml et al. 2002a, b; Ottenschläger 


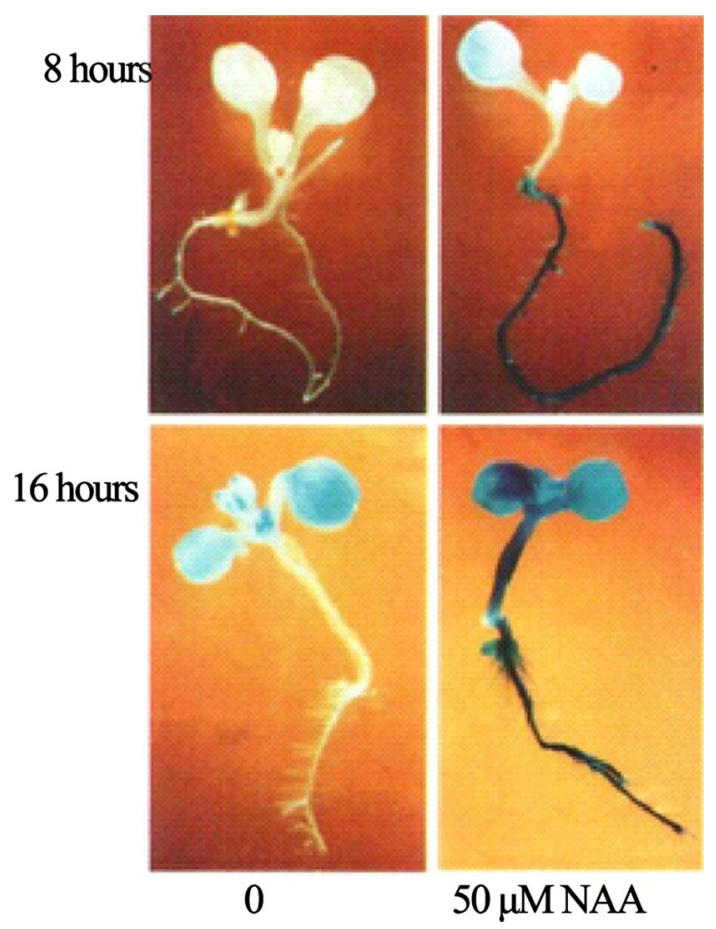

Fig. 4 Histochemical staining for GUS activity in Arabidopsis seedlings transformed with DR5 $(\times 7)-G U S$. Seedlings were treated for $24 \mathrm{~h}$ with $50 \mu \mathrm{M}$ 1-NAA (right) or $\mathrm{H}_{2} \mathrm{O}$ (left) and then stained for GUS activity for $\sim 8 \mathrm{~h}$ (top) or $16 \mathrm{~h}$ (bottom). Cited from Ulmasov et al. (1997)

et al. 2003; Willemsen et al. 2003; Laplaze et al. 2007; Ohashi-Ito and Bergmann, 2007; Petersson et al. 2009).

SCARECROW (SCR) gene encodes a putative transcription factor (Di Laurenzio et al. 1996) that is first expressed in QC precursor cells during embryogenesis, after which it extends to the initial cells for the ground tissue (cortex and endodermis) (Wysocka-Diller et al. 2000). Because SCR gene regulates an asymmetric cell division that is essential for generating the radial organization of the Arabidopsis roots (Di Laurenzio et al. 1996) and is involved in positioning the stem cell niche in the Arabidopsis root meristem (Sabatini et al. 2003), its fusion constructs with GFP or GUS are widely used to study root development (Table 2).

All the novel plant experimental materials provide us with information about root developmental processes, especially initiation of lateral roots and QC activity. Since root brain hypothesis have been accepted gradually (Baluška et al. 2009, 2010), some of the plant experimental materials will be useful for investigation on the functions of root tips. In view of complexity of root brain, new plant experimental materials will be developed, especially those involved in neurotransmitters.

Additionally, since root development is affected by other phytohormones, such as ethylene (Rahman et al. 2001; Stepanova et al. 2007), cytokinin (Aloni et al. 2006;
Laplaze et al. 2007), and nitric oxide (Correa-Aragunde et al. 2004, 2006; Stöhr and Stremlau 2006), novel transgenic plants, like the above-mentioned transgenic lines with DR::GFP and DR5::GUS, are needed for investigation on the effects of ethylene, cytokinin and nitric oxide on root development, especially their effects on lateral root formation. New techniques and experimental materials are needed to promote study of root development.

\section{Concluding remarks}

In view of multiple functions of roots, we have to face crypticity and high plasticity of root systems. Development of new techniques for data acquisition and analysis and experimental materials will help us overcome difficulties and understand more details about root functions and root dynamics.

Acknowledgments We thank Dr. Soo-Un Kim in Seoul National University for reviewing the manuscript. This work is supported by the project of public benefits in China (No. 201503221) and the open fund in the Institute of Root Biology, Yangtze University.

\section{References}

Aida M, Beis D, Heidstra R, Willemsen V, Blilou I, Galinha C, Nussaume L, Noh YS, Amasino R, Scheres B (2004) The PLETHORA genes mediate patterning of the Arabidopsis root stem cell niche. Cell 119:109-120

al Hagrey SA (2007) Geophysical imaging of root-zone, trunk, and moisture heterogeneity. J Exp Bot 58:839-854

Aloni R, Aloni E, Langhans M, Ulirich CI (2006) Role of cytokinin and auxin in shaping root architecture: regulating vascular differentiation, lateral root initiation, root apical dominance and root gravitropism. Ann Bot 97:883-893

Baluška F, Mancuso S, Volkmann D, Barlow PW (2009) The 'rootbrain' hypothesis of Charles and Francis Darwin: revival after more than 125 years. Plant Signal Behav 4:1121-1127

Baluška F, Mancuso S, Volkmann D, Barlow PW (2010) Root apex transition zone: a signalling-response nexus in the root. Trends Plant Sci 15:402-408

Barron JL, Liptay A (1994) Optical flow to measure minute increments in plant growth. Bioimaging 2:57-61

Barron JL, Fleet DJ, Beauchemin SS (1994) Performance of optical flow techniques. Int J Comput Vis 12:43-77

Barton CVM, Montagu KD (2004) Detection of tree roots and determination of root diameters by ground penetrating radar under optimal conditions. Tree Physiol 24:1323-1331

Basu P, Pal A, Lynch JP, Brown KM (2007) A novel image analysis technique for kinematic study of growth and curvature. Plant Physiol 145:305-316

Bengough AG, McKenzie BM, Hallett PD, Valentine TA (2011) Root elongation, water stress, and mechanical impedance: a review of limiting stresses and beneficial root tip traits. J Exp Bot 62:59-68

Berntson GM (1994) Root systems and fractals: how reliable are calculations of fractal dimensions? Ann Bot 73:281-284

Berntson GM, Woodward FI (1992) The root system architecture and development of Senecio vulgaris in elevated $\mathrm{CO}_{2}$ and drought. Funct Ecol 6:324-333 
Bhalerao RP, Eklof J, Ljung K, Marchant A, Bennett M, Sandberg G (2002) Shoot-derived auxin is essential for early lateral root emergence in Arabidopsis seedlings. Plant J 29:325-332

Birnbaum K, Shasha DE, Wang JY, Jung JW, Lambert GM, Galbraith DW, Benfey PN (2003) A gene expression map of the Arabidopsis root. Science 302:1956-1960

Boumma TJ, Nielsen KL, Koutstaal B (2000) Sample preparation and scanning protocol for computerised analysis of root length and diameter. Plant Soil 218:185-196

Bushamuka VN, Zobel RW (1998) Differential genotypic and root type penetration of compacted soil layer. Crop Sci 38:776-781

Busscher WJ, Lipiec J, Bauer PJ, Carter TE Jr (2000) Improved root penetration of soil hard layers by a selected genotype. Comm Soil Sci Plant Analysis 31:3089-3101

Butnor JR, Doolittle JA, Johnsen KH, Samuelson L, Stokes T, Kress L (2003) Utility of ground-penetrating radar as a root biomass survey tool in forest systems. Soil Sci Soc Am J 67:1607-1615

Casimiro I, Marchant A, Bhalerao RP, Beeckmand T, Dhooge S, Swarup R, Graham N, Inze D, Sandberg G, Casero PJ, Bennett M (2001) Auxin transport promotes Arabidopsis lateral root initiation. Plant Cell 13:843-852

Clark RT, MacCurdy RB, Jung JK, Shaff JE, McCouch SR, Aneshansley DJ, Kochian LV (2010) Three-dimensional root phenotyping with a novel imaging and software platform. Plant Physiol 156:455-465

Clausnitzer V, Hopmans JW (1994) Simultaneous modeling of transient three- dimensional root growth and soil water flow. Plant Soil 164:299-314

Colón-Carmona A, You R, Haimovitch-Gal T, Doerne P (1999) Spatio-temporal analysis of mitotic activity with a labile cyclinGUS fusion protein. Plant J 20:503-508

Correa-Aragunde N, Graziano M, Lamattina L (2004) Nitric oxide plays a central role in determining lateral root development in tomato. Planta 218:900-905

Correa-Aragunde N, Graziano M, Chevalier C, Lamattina L (2006) Nitric oxide modulates the expression of cell cycle regulatory genes during lateral root formation in tomato. J Exp Bot 57:581-588

Costa C, Dwyer LM, Dutilleul P, Foroutan-pour K, Liu A, Hamel C, Smith DL (2003) Morphology and fractal dimension of root systems of maize hybrids bearing the leafy trait. Can J Bot 81:706-713

Danjon F, Barker DH, Drexhage M, Stokes A (2008) Using threedimensional plant root architecture in models of shallow-slope stability. Ann Bot 101:1281-1293

Danjon F, Bert D, Godin C, Trichet P (1999a) Structural root architecture of 5-year-old Pinus pinaster measured by 3D digitising and analysed with AMAPmod. Plant Soil 217:49-63

Danjon F, Reubens B (2008) Assessing and analyzing 3D architecture of woody root systems, a review of methods and applications in tree and soil stability, resource acquisition and allocation. Plant Soil 303:1-34

Danjon F, Sinoquet H, Godin C, Colin F, Drexhage M (1999b) Characterisation of structural tree root architecture using 3D digitising and AMAPmod software. Plant Soil 211:241-258

Di Iorio A, Lasserre B, Scippa GS, Chiatante D (2005) Root system architecture of Quercus pubescens trees growing on different sloping conditions. Ann Bot 95:351-361

Di Laurenzio L, Wysockadiller J, Malamy JE, Pysh L, Helariutta Y, Freshour G, Hahn MG, Feldmann KA, Benfey PN (1996) The SCARECROW gene regulates an asymmetric cell division that is essential for generating the radial organization of the Arabidopsis root. Cell 86:423-433

Ding Z, Friml J (2010) Auxin regulates distal stem cell differentiation in Arabidopsis roots. Proc Natl Acad Sci USA 107:12046-12051
Doerner P, Jørgensen J-E, You R, Steppuhn J, Lamb C (1996) Control of root growth and development by cyclin expression. Nature 380:520-523

Draye X. 2008. Xavier Draye's profile. http://www.uclouvain.be/en30461. Accessed 16 June 2009

Dubrovsky JG, Gambetta GA, Hernadez-Barrera A, Shishkova S, Gonzalez I (2006) Lateral root initiation in Arabidopsis: developmental window, spatial patterning, density and predictability. Ann Bot 97:903-915

Eghball B, Settimi JR, Maranville JW, Parkhurst AM (1993) Fractal analysis for morphological description of corn roots under nitrogen stress. Agron J 85:287-289

Fang S, Yan X, Liao H (2009) 3D reconstruction and dynamic modeling of root architecture in situ and its application to crop phosphorus research. Plant J 60:1096-1108

Fitter AH, Stickland (1991) Architectural analysis of plant root systems 2. Influence of nutrient supply on architecture in contrasting plant species. New Phytol 118:383-389

Fitter AH, Stickland TR (1992) Fractal characterization of root system architecture. Funct Ecol 6:632-635

French A, Ubeda-Tomas S, Holman TJ, Bennett MJ, Pridmore T (2009) High-throughput quantification of root growth using a novel image-analysis tool. Plant Physiol 150:1784-1795

Friml J, Benkova E, Blilou I, Wisniewska J, Hamann T, Ljung K, Woody S, Sandberg G, Scheres B, Jurgens G, Palme K (2002a) AtPIN4 mediates sink-driven auxin gradients and root patterning in Arabidopsis. Cell 108:661-673

Friml J, Wisniewska J, Benkova E, Mendgen K, Palme K (2002b) Lateral relocation of auxin efflux regulator PIN3 mediates tropism in Arabidopsis. Nature 415:806-809

Gahoonia TS, Nielsen NE (2004) Root traits as tools for creating phosphorus efficient crop varieties. Plant Soil 260:47-57

Gan Y, Bernreiter A, Filleur S, Abram B, Forde BG (2012) Overexpressing the ANR1 MADS-box gene in transgenic plants provides new insights into its role in the nitrate regulation of root development. Plant Cell Physiol 53:1003-1016

Gregory PJ (2006) Plant roots: their growth, activity, and interaction with soils. Blackwell Publishing, Oxford

Gregory PJ, Hutchison DJ, Read DB, Jenneson PM, Gilboy WB, Morton EJ (2003) Non-invasive imaging of roots with high resolution X-ray micro-tomography. Plant Soil 255:351-359

Gruber BD, Giehl RF, von Friedel S, Wiren N (2013) Plasticity of the Arabidopsis root system under nutrient deficiencies. Plant Physiol 163:161-179

Heeraman DA, Hopmans JW, Clausnitzer V (1997) Three dimensional imaging of plant roots in situ with X-ray computed tomography. Plant Soil 189:167-179

Henry A, Gowda VRP, Torres RO, McNally KL, Serraj R (2011) Variation in root system architecture and drought response in rice (Oryza sativa): phenotyping of the OryzaSNP panel in rainfed lowland fields. Field Crops Research 120:205-214

Hill JO, Simpson RJ, Moore AD, Chapman DF (2006) Morphology and response of roots of pasture species to phosphorus and nitrogen nutrition. Plant Soil 286:7-19

Himanen K, Boucheron E, Vanneste S, de Almeida Engler J, Inze D, Beeckman T (2002) Auxin-mediated cell cycle activation during early lateral root initiation. Plant Cell 14:2339-2351

Hutchison CE, Li J, Argueso C, Gonzalez M, Lee E, Lewis MW, Maxwell BB, Perdue TD, Schaller GE, Alonso JM, Ecker JR, Kieber JJ (2006) The Arabidopsis histidine phosphotransfer proteins are redundant positive regulators of cytokinin signaling. Plant Cell 18:3073-3087

International Atomic Energy Agency (2006) Mutational analysis of root characters in food plants. International Atomic Energy Agency, Vienna 
Ioio RD, Linhares FS, Scacchi E, Casamitjana-Martinez E, Heidstra R, Costantino P, Sabatini S (2007) Cytokinins determine Arabidopsis root-meristem size by controlling cell differentiation. Curr Biol 17:678-682

Ishikawa H, Evans ML (1997) Novel software for analysis of root gravitropism: comparative response patterns of Arabidopsis wild-type and axrl seedlings. Plant, Cell Environ 20:919-928

Iwamoto A, Kondo E, Fujihashi H, Sugiyama M (2013) Kinematic study of root elongation in Arabidopsis thaliana with a novel image-analysis program. J Plant Res 126:187-192

Iyer-Pascuzzi AS, Symonova O, Mileyko Y, Hao Y, Belcher H, Harer J, Weitz JS, Benfey PN (2010) Imaging and analysis platform for automatic phenotyping and trait ranking of plant root systems. Plant Physiol 152:1148-1157

Jain A, Poling MD, Karthikeyan AS, Blakeslee JJ, Peer WA, Titapiwatanakun T, Murphy AS, Raghothama KG (2007) Differential effects of sucrose and auxin on localized phosphate deficiency-induced modulation of different traits of root system architecture in Arabidopsis. Plant Physiol 144:232-247

Kaspar TC, Bland WL (1992) Soil temperature and root growth. Soil Sci 154:290-299

Kurup S, Runions J, Kohler U, Laplaze L, Hodge S, Haseloff J (2005) Marking cell lineages in living tissues. Plant J 42:444-453

Laplaze L, Parizot B, Baker A, Ricaud L, Martiniere A, Auguy F, Franche C, Nussaume L, Bogusz D, Haseloff J (2005) GAL4GFP enhancer trap lines for genetic manipulation of lateral root development in Arabidopsis thaliana. J Exp Bot 56:2433-2442

Laplaze L, Benkov E, Casimiro I, Maes L, Vanneste S, Swarup R, Weijers D, Calvo V, Parizot B, Herrera-Rodriguez MB, Offringa R, Graham N, Doumas P, Firml J, Bougsz D, Beeckman T, Bennett M (2007) Cytokinins act directly on lateral root founder cells to inhibit root initiation. Plant Cell 19:3889-3900

Laskowski M (2013) Lateral root initiation is a probabilistic event whose frequency is set by fluctuating levels of auxin response. J Exp Bot 64:2609-2617

Linkohr BI, Williamson LC, Fitter AH, Leyser HMO (2002) Nitrate and phosphate availability and distribution have different effects on root system architecture of Arabidopsis. Plant J 29:751-760

Lontoc-Roy M, Dutilleul P, Prasher SO, Han L, Smith DL (2005) Computed tomography scanning for three-dimensional imaging and complexity analysis of developing root systems. Can J Bot 83:1434-1442

Lynch J (1995) Root Architecture and Plant Productivity. Plant Physiol 109:7-13

Mackay AD, Barber SA (1984) Soil temperature effects on root growth and phosphorus uptake by corn. Soil Sci Soc Am J 48:818-823

Mairhofer S, Zappala S, Tracy SR, Sturrock C, Bennett M, Mooney SJ, Pridmore T (2012) RooTrak: automated recovery of threedimensional plant root architecture in soil from X-ray microcomputed tomography images using visual tracking. Plant Physiol 158:561-569

Mairhofer S, Zappala S, Tracy S, Sturrock C, Bennett MJ, Mooney SJ, Pridmore TP (2013) Recovering complete plant root system architectures from soil via X-ray $\mu$-Computed Tomography. Plant Methods 9:8. doi:10.1186/1746-4811-9-8

Malamy JE, Benfey PN (1997) Organization and cell differentiation in lateral roots of Arabidopsis thaliana. Development 124:33-44

Mandelbrot B (1975) Les Objets Fractals: Forme Hasard et Dimension. Flammarion, Paris

Manschadi AM, Christopher J, deVoil P, Hammer GL (2006) The role of root architectural traits in adaptation of wheat to waterlimited environments. Funct Plant Biol 33:823-837

Manschadi AM, Hammer GL, Christopher JT, deVoil P (2008) Genotypic variation in seedling root architectural traits and implications for drought adaptation in wheat (Triticum aestivum L.). Plant Soil 303:115-129

Miller ND, Parks BM, Spalding EP (2007) Computer-vision analysis of seedling responses to light and gravity. Plant J 52:374-381

Mooney SJ (2002) Three-dimensional visualization and quantification of soil macroporosity and water flow patterns using computed tomography. Soil Use Manag 18:142-151

Mooney SJ, Pridmore TP, Helliwell J, Bennett MJ (2012) Developing $\mathrm{X}$-ray computed tomography to non-invasively image 3-D root systems architecture in soil. Plant Soil 352:1-22

Nadezhdina N, Čermák J (2003) Instrumental methods for studies of structure and function of root systems of large trees. J Exp Bot 54:1511-1521

Nakamura A, Higuchi K, Goda H, Fujiwara MT, Sawa S, Koshiba T, Shimada Y, Yoshida S (2003) Brassinolide induces IAA5, IAA19, and DR5, a synthetic auxin response element in Arabidopsis, implying a cross talk point of brassinosteroid and auxin signaling. Plant Physiol 133:1843-1853

Nielsen KL, Lynch JP, Weiss HN (1997) Fractal geometry of bean root systems: correlation between spatial and fractal dimension. Amer J Bot 84:26-33

Nielsen KL, Miller CR, Beck D, Lynch JP (1999) Fractal geometry of root systems: field observations of contrasting genotypes of common bean (Phaseolus vulgaris L.) grown under different phosphorus regimes. Plant Soil 206:181-190

Ohashi-Ito K, Bergmann DC (2007) Regulation of the Arabidopsis root vascular initial population by LONESOME HIGHWAY. Development 134:2959-2968

Oppelt AL, Kurth W, Dzierzon H, jentschke G, Godbold DL (2000) Structure and fractal dimensions of root systems of four cooccurring fruit tree species from Botswana. Ann For Sci $57: 463-475$

Ottenschläger I, Wolff P, Wolverton C, Bhalerao RP, Sandberg G, Ishikawa H, Evans M, Palme K (2003) Gravity-regulated differential auxin transport from columella to lateral root cap cells. Proc Natl Acad Sci USA 100:2987-2991

Peret B, Clement M, Nussaume L, Desnos T (2011) Root developmental adaptation to phosphate starvation: better safe than sorry. Trends Plant Sci 16:442-450

Perret JS, Al-Belushi ME, Deadman M (2007) Non-destructive visualization and quantification of roots using computed tomography. Soil Biol Biochem 39:391-399

Pierret A, Capowiez Y, Moran CJ, Kretzschmar A (1999) X-ray computed tomography to quantify tree rooting spatial distributions. Geoderma 90:307-326

Pierret A, Latchackak K, Chathanvongsa P, Sengtaheuanghoung O, Valentin C (2007) Interactions between root growth, slope and soil detachment depending on land use: a case study in a small mountain catchment of Northern Laos. Plant Soil 301:51-64

Petersson SV, Johansson AI, Kowalczyk M, Makoveychuk A, Wang JY, Moritz T, Grebe M, Benfey PN, Sandberg G, Jung K (2009) An auxin gradient and maximum in the Arabidopsis root apex shown by high-resolution cell-specific analysis of IAA distribution and synthesis. Plant Cell 21:1659-1668

Playsted CWS, Johnston ME, Ramage CM, Edwards DG, Cawthray GR, Lambers H (2006) Functional significance of dauciform roots: exudation of carboxylates and acid phosphatase under phosphorus deficiency in Caustis blakei (Cyperaceae). New Phytol 170:491-500

Pound MP, French AP, Atkinson JA, Wells DM, Bennett MJ, Pridmore T (2013) RootNav: navigating images of complex root architectures. Plant Physiol 162:1802-1814

Pregitzer KS, deforest JL, Burton AJ, Hendrick RL (2002) Fine root architecture of nine northern American trees. Ecol Monogr 72:293-309 
Qi X, Qi J, Wu Y (2007) RootLM: a simple color image analysis program for length measurement of primary roots in Arabidopsis. Plant Root 1:10-16

Rahman A, Amakawa T, Goto N, Tsurumi S (2001) Auxin is a positive regulator for ethylene-mediated response in the growth of Arabidopsis roots. Plant Cell Physiol 42:301-307

Sabatini S, Beis D, Wolkenfelt H, Murfett J, Guilfoyle T, malamy J, Benfey P, Leyser O, Bechtold N, Weisbeek P, Scheres B (1999) An auxin-dependent distal organizer of pattern and polarity in the Arabidopsis root. Cell 99:463-472

Sabatini S, Heidstra R, Wildwater M, Scheres B (2003) SCARECROW is involved in positioning the stem cell niche in the Arabidopsis root meristem. Genes Develop 17:354-358

Shan LS, Li Y, Ren W, Su SP, Dong QL, Geng DM (2013) Root architecture of two desert plants in central Hexi Corridor of Northwest China. Chinese J Appl Ecol 24:25-31

Shane MW, Cawthray GR, Cramer MD, Kuo J, Lambers H (2006) Specialized 'dauciform' roots of Cyperaceae are structurally distinct, but functionally analogous with 'cluster' roots. Plant, Cell Environ 29:1989-1999

Shaul O, Mironov V, Burssens S, Van Montagu M, Inzé D (1996) Two Arabidopsis cyclin promoters mediate distinctive transcriptional oscillation in synchronized tobacco BY-2 cells. Proc Natl Acad Sci USA 93:4868-4872

Shen J, Li C, Mi G, Li L, Yuan L, Jiang R, Zhang F (2013) Maximizing root/rhizosphere efficiency to improve crop productivity and nutrient use efficiency in intensive agriculture of China. J Exp Bot 64:1181-1192

Smit AL, Bengough AG, Engels C, van Noordwijk M, Pellerin S, van de Geijn SC (2000) Root methods: a handbook. Springer-Verlag, Berlin

Spalding EP (2009) Phytomorph. http://phytomorph.wisc.edu/. Accessed 16 June 2009

Stepanova AN, Yun J, Likhacheva AV, Aonso JM (2007) Multilevel interactions between ethylene and auxin in Arabidopsis roots. Plant Cell 19:2169-2185

Stöhr C, Stremlau S (2006) Formation and possible roles of nitric oxide in plant roots. J Exp Bot 57:463-470

Sugimoto K, Jiao Y, Meyerowitz EM (2010) Arabidopsis regeneration from multiple tissues occurs via a root development pathway. Develop Cell 18:463-471

Sun H-L, Li S-C, Xiong W-L, Yang Z-R, Cui B-S, Yang T (2008) Influence of slope on root system anchorage of Pinus yunnanensis. Ecol Engin 32:60-67

Swarup R, Kramer EM, Perry P, Knox K, Leyser HMO, Haseloff J, Beemster GTS, Bhalerao R, Bennett MJ (2005) Root gravitropism requires lateral root cap and epidermal cells for transport and response to a mobile auxin signal. Nat Cell Biol 7: $1057-1065$

Tatsumi J, Yamauchi A, Kono Y (1989) Fractal analysis of plant root systems. Ann Bot 64:499-503

Tracy S, Black C, Roberts J, Mooney S (2010a) Visualising the effect of compaction on root architecture in soil using X-ray Computed Tomography.In: 19th World Congress of Soil Science, Soil Solutions for a Changing World. 1-6 August 2010, Brisbane, Australia

Tracy SR, Roberts JA, Black CR, McNeill A, Davidson R, Mooney SJ (2010b) The $\mathrm{x}$-factor: visualizing undisturbed root architecture in soils using X-ray computed tomography. J Exp Bot 61:311-313

Tracy SR, Black CR, Roberts JA, McNeill A, Davidson R, Tester M, Samec M, Korosak D, Sturrock C, Mooney SJ (2012a)
Quantifying the effect of soil compaction on three varieties of wheat (Triticum aestivum L.) using X-ray micro computed tomography (CT). Plant Soil 353:195-208

Tracy SR, Black CR, Roberts JA, Sturrock C, Mairhofer S, Craigon J, Mooney S (2012b) Quantifying the impact of soil compaction on root system architecture in tomato (Solanum lycopersicum) by X-ray micro-computed tomography. Ann Bot 110:511-519

Ulmasov T, Murfett J, Hagen G, Guilfoyle TJ (1997) Aux/IAA proteins repress expression of reporter genes containing natural and highly active synthetic auxin response elements. Plant Cell 9:1963-1971

van der Weele CM, Jiang HS, Palaniappan KK, Ivanov VB, Palaniappan K, Baskin TI (2003) A new algorithm for computational image analysis of deformable motion at high spatial and temporal resolution applied to root growth: roughly uniform elongation in the meristem and also, after an abrupt acceleration, in the elongation zone. Plant Physiol 132:1138-1148

Vidal EA, Araus V, Lu C, Parry G, Green PJ, Coruzzi GM, Gutierrez RA (2010) Nitrate-responsive miR393/AFB3 regulatory module controls root system architecture in Arabidopsis thaliana. Proc Natl Acad Sci USA 107:4477-4482

Waki T, Miyashima S, Nakanishi M, Ikeda Y, Hashimoto T, Nakajima K (2013) A GAL4-based targeted activation tagging system in Arabidopsis thaliana. Plant J 73:357-367

Walk TC, Van Erp E, Lynch JP (2004) Modelling applicability of fractal analysis to efficiency of soil exploration by roots. Ann Bot 94:119-128

Walter A, Silk WK, Schurr U (2000) Effect of soil pH on growth and cation deposition in the root tip of Zea mays L. J Plant Growth Regul 19:65-76

Walter A, Spies H, Terjung S, Küsters R, Kirchgeßner N, Schurr U (2002) Spatio-temporal dynamics of expansion growth in roots: automatic quantification of diurnal course and temperature response by digital image sequence processing. J Exp Biol 53:689-698

Wang Z, Guo D, Wang X, Gu J, Mei L (2006) Fine root architecture, morphology, and biomass of different branch orders of two Chinese temperate tree species. Plant Soil 288:155-171

Wang H, Siopongco J, Wade LJ, Yamauchi A (2009) Fractal analysis on root systems of rice plants in response to drought stress. Environ Exp Bot 65:338-344

White PJ, George TS, Dupuy LX, Karley AJ, Valentine TA, Wiesel L, Wishart J (2013) Root traits for infertile soils. Front Plant Sci 4:193. doi:10.3389/fpls.2013.00193

Willemsen V, Friml J, Grebe M, van de Toorn A, Palme K, Scheres B (2003) Cell polarity and PIN protein positioning in Arabidopsis require STEROL METHYLTRANSFERASE1 function. Plant Cell 15:612-625

Williamson LC, Ribrioux SPCP, Fitter AH, Leyser HMO (2001) Phosphate availability regulates root system architecture in Arabidopsis. Plant Physiol 126:875-882

Wu C, Wei X, Sun H-L, Wang Z-Q (2005) Phosphate availability alters lateral root anatomy and root architecture of Fraxinus mandshurica rupr. seedlings. J Integ Plant Biol 47:292-301

Wysocka-Diller JW, Helariutta Y, Fukaki H, Malamy JE, Benfey PN (2000) Molecular analysis of SCARECROW function reveals a radial patterning mechanism common to root and shoot. Development 127:595-603

Zhang H, Forde BG (1998) An Arabidopsis MADS box gene that controls nutrient-induced changes in root architecture. Science 279:407-409 